\title{
A politização sacerdotal como iconoclastia religiosa: o caso dos dominicanos engajados no Movimento Cristãos-Marxistas ${ }^{1}$
}

Yann Raison du Cleuziou ${ }^{2}$

\section{Resumo}

Após maio de 1968, alguns padres se engajam na política colocando em evidência sua autoridade sacerdotal. Eles esperam desse modo contribuir com o engajamento da Igreja na luta de classes e, além, disso, dar novamente à fé cristã sua radicalidade profética. Sua mobilização política tem, portanto, uma finalidade religiosa reformadora. É essa forma de politização da competência sacerdotal que é aqui estudada, em particular com o exemplo dos dominicanos da Província da França, membros do movimento Cristãos-Marxistas (1974-1978).

Palavras-chave: Catolicismo. Dominicanos. Marxismo. Politização.

\section{Introdução}

Em 19 de abril de 1971, Michel Bosquet consagra um artigo do Le Nouvel Observateur aos "capeláes da subversão". O subtítulo é explícito: "Quando o clero aterroriza o patronato". O jornalista relata a adoçáo de uma postura contestatária por uma parte dos jovens sacerdotes católicos. O ministro do interior Raymond Marcellin se inquieta com a ação "subversiva" de uma centena de capeláes católicos cuja metade estaria localizada na regiáo parisiense. Michel Bosquet observa que eles são obviamente mais numerosos ainda. Somente na diocese de Nantes, uma centena de capeláes da ação católica vem

Tradução de Wheriston Silva Neris.

2 Maître de Conférences em Ciência Política, Centre Émile Durkheim, Université de Bordeaux.

E-mail: raison_du_cleuziou@yahoo.fr. 
proclamar sua concordância com "as questôes que são o núcleo do combate da classe trabalhadora” (BOUSQUET, 1971, p. 27)³.

Em 1972, René Rémond confere uma autoridade a essa observação jornalística ${ }^{4}$. Ele constata que uma nova relação dos clérigos com a política está tomando forma. Sua característica é o engajamento político à esquerda associado a uma posição crítica com relação à autoridade eclesial (REMOND, 1972). Os teólogos e capelães seriam os clérigos mais tocados por esta dupla postura contestatória. O sacerdote e sociólogo Michel Brion (1972, p. 37) confirma essa tendência na sequência de uma importante pesquisa: "[...] ouvimos os sacerdotes dizerem que o Evangelho provavelmente não é compatível com uma política diferente do socialismo" ${ }^{5}$. Três meses antes das eleiçôes legislativas de março de 1973, uma pesquisa mostra que, politicamente, o jovem clero tem tendência a agir inversamente aos mais velhos e ao conjunto dos fiéis praticantes, escolhendo, em uma razão de dois terços, votar à esquerda ou mesmo à extrema esquerda (SONDAGES, 1973, p. 26-30). Nas eleiçóes legislativas de 1977, esta observação é renovada: 69\% dos sacerdotes de menos de 40 anos declaram sua intenção de votar em um candidato de esquerda. Esta orientação representa apenas $9 \%$ dos sacerdotes com mais de 60 anos e 16 a $17 \%$ de católicos praticantes de todas as idades.

Em 1978, Christel Peyrefitte refina e confirma as descobertas de René Rémond e Michel Brion. A propensão a votar na esquerda corresponde a uma maneira específica de considerar o papel sacerdotal. Ela observa que os jovens sacerdotes veem na "presença no mundo" uma exigência mais imperativa do que a observância dos ritos e a celebração dos sacramentos (PEYREFITTE, 1978). O clero que vota na esquerda é nitidamente menos respeitoso com a obrigação de celebrar a missa cotidianamente do que o clero à direita. Sua vida sacerdotal se desloca dos atos litúrgicos para uma militância social e política. Sinal visível dessa mudança: a aparência dos sacerdotes evolui. Uma pesquisa IFOP de fevereiro de 1976 revela uma relaçáo muito forte entre o grau de marcação religiosa da vestimenta e o voto: enquanto que $2,4 \%$ dos sacerdotes que usam ocasionalmente a batina votaram em François Mitterrand em

\footnotetext{
3 Intitulado Les aumôniers de la subversion. Quand le clergé terrifie le patronat

4 Em L'évolution du comportement des prêtres en matière politique.

5 Ver, também, p. 83-84.
} 
1974 , esse é o caso de $27 \%$ daqueles que não nunca usam batina, e de $41 \%$ daqueles que não nunca fixam a cruz na parte detrás de seu casaco (SUAUD, 1982, p. 237) ${ }^{6}$. Christel Peyreffite (1978, p. 164) estima que no conjunto dos sacerdotes, o núcleo duro desse jovem clero com um estilo de vida engajado é de cerca de $8 \%$; seguida imediatamente por uma franja "menos determinada” de cerca de 15 a $20 \%$ do total de clérigos. Os padres que militam na política à esquerda representariam em torno de $6 \%$. Mas como o notam René Rémond e Christel Peyrefitte, esse clero tem uma influência muito superior à sua importância numérica por três razóes: ele é considerado como o clero do "futuro" e se beneficia a esse título de um acréscimo de autoridade junto às autoridades eclesiais; ele é muito inclinado a se exprimir contrariamente à maioria que permanece silenciosa; e, finalmente, ele está em contato com os militantes católicos procedentes das classes médias que assumem as posiçôes dominantes no campo religioso.

A história do engajamento à esquerda de uma parte dos católicos militantes é desde então bem conhecida e as trajetórias de politização de muitos sacerdotes não renegam essa trama (FOUILLOUX, 1977, p. 102; PELLETIER; SCHLEGEL, 2015) ${ }^{7}$. Como demonstra Claude Grignon, a Igreja é moldada por um efeito de homologia que se opera entre o clero formado nos anos 1950 e 1960, dispondo de uma relação distanciada com relação à instituição religiosa e afeita aos ministérios extraparoquiais e os leigos pertencentes às novas classes médias "sociologicamente inclinadas para a esquerda", que assumem posiçôes dominantes na Igreja nesses mesmos anos (GRIGNON, 1977). Esses católicos de "profissōes intermediárias", em ascensão social, vão contestar a cultura religiosa burguesa e conservadora a fim de se distinguir dela e de legitimar a transformação de que se consideram portadores, tanto no seio do catolicismo quanto na sociedade. $\mathrm{O}$ novo estilo sacerdotal praticado pelo jovem clero responde assim às expectativas desse novo público, bem como às suas próprias expectativas na medida em que os sacerdotes, em nome da mudança social a ser feita no futuro, compartilham uma necessidade idêntica de reconversão de suas disposiçôes religiosas em novas posições econômicas, sociais e culturais (BOURDIEU; SAINT-MARTIN, 1982; ROUSSEAU, 1982).

\footnotetext{
Consultar La vocation. Paris : Minuit, 1978.

7 Ver, também, o álbum ilustrado Les mauvaises gens: une histoire de militants (DAVODEAU, 2005).
} 
Os repertórios de ação desses padres politizados não foram objeto de estudo sistemático e seus traços são encontrados em fontes dispersas (DELOYE, 2006) ${ }^{8}$. Preencher essa lacuna, sem dúvida, proporcionaria uma compreensáo mais aprofundada das inflexôes para a esquerda da trajetória de vários dos militantes católicos. Pois, em seus testemunhos, não é raro perceber a influência ou mesmo a incitação direta dos padres (PAGIS, 2010). Durante os anos 1960 e 1970, as articulaçôes possíveis entre a fé e a política são múltiplas e concorrentes (ROUSSEAU, 2013; SOULAGE, 2015). As modalidades de engajamento de padres à esquerda diferem manifestadamente segundo a inclinação religiosa e política dos interessados. Por exemplo, no que diz respeito à documentação disponível sobre aqueles que entraram em partidos ou em movimentos políticos: duas modalidades de afiliação podem ser distinguidas. A primeira é uma realização da afirmação de que o padre é um homem ordinário e que ele não pode derrogar como tal a necessidade que incumbe a cada um de se engajar politicamente para construir um mundo mais justo9. O engajamento torna possível então aperfeiçoar a trajetória de humanização que muitos sacerdotes reivindicam no final da década de 1960 (RAISON DU CLEUZIOU, 2015). A segunda modalidade é mais clerical, pois o status do sacerdote é instrumentalizado para dar à adesão partidária ou à mobilização os efeitos de autoridade específicos na Igreja e na política: em 25 de dezembro de 1972, os sacerdotes da diocese de Valence decidem fazer uma greve da Missa da Meia-Noite em solidariedade aos imigrantes ilegais (SIMEANT, $2015)^{10}$. É essa forma de politização da competência sacerdotal que gostaríamos de estudar aqui, mais particularmente através do exemplo do dominicano da Província da França, Paul Blanquart, um dos fundadores do movimento Cristão-marxista (1974-1978).

\section{Uma trajetória de politização}

Paul Blanquart nasceu em 1934. Ele era originário de uma família de Pas de Calais marcada ao mesmo tempo pelo cristianismo e pelo movimento trabalhista. Desde os 17 anos, assina La Quinzaine e o Esprit e seguiu o

\footnotetext{
8 Não existe um trabalho de conjunto equivalente ao de Yves Déloye para o periodo precedente.

9 Por exemplo: Blond, 1971, p. 256; Barre, 2014, p. 159-169.

10 Mais detalhes em Siméant, 2015, p. 39-62.
} 
desenvolvimento do progressismo cristão. Durante seus estudos, milita na União Nacional dos Estudantes da França (UNEF) e participa como delegado estudantil do congresso fundador da Nouvelle Gauche (1956). Ele se define como companheiro de rota do Partido Comunista Francês (PCF) e voto comunista. Em 1955, ele escolhe entrar na Província Dominicana da França. As sançôes sofridas pelos dominicanos franceses no caso dos padres-operários

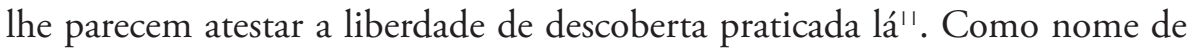
religiáo ele escolhe adicionar Emmanuel ao seu prenome de batismo em referência a Emmanuel Mounier.

Mobilizado durante a Guerra da Argélia, ele adota, como a maioria dos dominicanos de sua geração, uma posição crítica (RAISON DU CLEUZIOU, 2013). Sem se juntar à Frente de Libertação Nacional (FLN), eles militam pelo diálogo e a negociaçáo. $\mathrm{O}$ seu engajamento os leva a manter, a todo o custo, o contato com as populaçóes argelinas que eles consideram tratadas com injustiça. Esta atitude evangélica é para eles tanto mais importante quanto eles temem que o cristianismo esteja comprometido somente com a cultura colonial francesa. A política de pacificação lhe permitirá viver mais integralmente essa exigência: Paul Blanquart cuida de uma escola. Esta orientação para os serviços sociais e médicos, as tarefas de ensino e ajuda às populações, responde à necessidade de conciliar as exigências religiosas com aquelas da mobilização no exército, ou mesmo de resistir à política militar e colonial de uma maneira discreta, porém, eficaz.

Nesse contexto, ele amadurece o caráter necessariamente político do engajamento religioso. Não é possível distinguir o temporal e o espiritual. A pertinência do testemunho evangélico exige um engajamento crítico contra a injustiça. Consequentemente, o sacerdote encontra-se comprometido com a ordem estabelecida que ele legitima por sua atitude passiva. Paul Blanquart lamentará não estar mais engajado contra a tortura e, sem dúvida, a radicalidade de seus engajamentos políticos subsequentes encontra aqui uma explicação.

Após 1962, o combate pela legalização da objeção de consciência será particularmente seguido e apoiado no convento de estudo dominicano do

$1 /$ Entrevista com Paul Blanquart, realizada em 28 de abril de 2005. 
Saulchoir ${ }^{12}$. O contexto internacional favorece igualmente o desejo de engajamento dos jovens religiosos. As lutas de libertação nacional, especialmente a do Vietnã, são acompanhadas com bastante interesse. Após o apelo à solidariedade com o povo vietnamita lançado pelo Témoignage Chrétien em 21 de abril de 1966, vários irmãos do Saulchoir, entre os quais Paul Blanquart, pedem permissão ao Provincial para dele participar ${ }^{13}$.

No interior da província dominicana da França, a Guerra da Argélia marcará profundamente o estudantado. A maioria dos irmãos mobilizados extrairá de sua experiência uma crítica às formas sacerdotais. A partilha da vida dos homens lhes parece a condição fundamental do testemunho evangélico. O modo de vida conventual separado da sociedade, que lhes é proposto pela Ordem Dominicana, parece fazer obstáculo às suas aspiraçóes missionárias. Paul Blanquart defende, então, a fecundidade da estratégia de desinstitucionalização adotada pelos padres-operários:

Eu digo frequentemente que nossa vida espiritual está “de cabeça para baixo", porque começamos a partir de um ambiente "construído", condicionado precisamente para encontrar Cristo. Mas essa é a melhor solução, porque dessa forma é do conceito que nós partimos. Eu penso na instituição, no sentido de regularidade, como o compreendia Peguy, por oposição à secularidade; e ele dizia que Cristo era secular. Submeter tudo a nossa regularidade, os tempos tradicionais do ofício de orações etc.[...] em particular, o testemunho, a vida apostólica, a regularidade em primeiro lugar, e uma vez esta estando assegurada, o resto; isso nos coloca em condição de reencontrar o Cristo. Contudo, nós ingressamos na vida religiosa para que isso seja mais fácil, e eu me questiono hoje se é bem esse o caso ${ }^{14}$.

Para Paul Blanquart, a mediação pessoal é a mais importante; a adesão a um corpo de saberes e de conceitos religiosos é secundária e somente legítima se for o fruto de um encontro com o Cristo, caso contrário é ideologia. Portanto, um mero testemunho de vida, mesmo que não seja reivindicado por um discurso que o justifique em nome de Cristo, conduz mais seguramente a Cristo do que um corpo de doutrinas ou práticas codificadas. Segundo Paul

12 Arquivos da Província Dominicana da França (APDF), III, 0, 84, Mesa redonda sobre a objeção de consciência proposta pelos freis Patrick Jacquemont, P. R. Clément, Alain Carron de la Carrière, Paul Blanquart, François Oliver, Michel Froidure, Yves Lebeaux, Gérard Mesnil, Bernard-Marie de La Gorce.

13 APDF, III, L, Estudantado, carta de Jean Mansir a Joseph Kopf, datada de 25 de abril de 1966.

14 APDF, IV, 20I, O, OI, Corbreuse, quinta-feira, I2 de setembro, testemunhos sobre o sacerdócio a partir das experiências de férias. 
Blanquart, a instituição religiosa não é uma via de acesso mais fácil a Cristo. Pelo contrário, ela é um obstáculo impondo a adesão a convençôes que não são evangélicas. Em 1964, enquanto que Paul Blanquart vai receber a ordenação sacerdotal, o padre Marneffe, então pai mestre, o repreendeu por somente reter o aspecto profético do sacerdócio e por esquecer a santidade de todos os sacerdotes que cumprem seu ministério.

Paul Blanquart orientou suas pesquisas para o marxismo e messianismos religiosos. Ele completou seus estudos com uma dissertação [thèse de lectorat] sobre "Contemporaneidade e Profetismo". Ele é nomeado mestre de conferências no Instituto Católico no final de seus estudos e ministra cursos sobre as relaçôes entre socialismos e religióes. Ele trabalha igualmente na crítica da sociedade de consumo na vertente dos trabalhos de Henri Lefebvre. Além disso, Blanquart se engaja em um diálogo seguido com os comunistas (Antoine Casanova, Roger Garaudy, André Moine) e defende a compatibilidade entre cristianismo e marxismo. De 1967 a 1968, Paul Blanquart organiza com o Irmáo Joseph Bussard quatro sessóes de descoberta do marxismo no convento de Saint-Jacques. São estudados os fundamentos teóricos, bem como os desenvolvimentos contemporâneos com Mao, Garaudy ou Althusser. Em janeiro de 1968, ele participa de um congresso de intelectuais em Havana e ultrapassa os limites do engajamento oficial. Ele assina com três outros sacerdotes um manifesto pelo engajamento na "luta revolucionária anti-imperialista".

Nós, sacerdotes católicos, delegados no Congresso Cultural de Havana, convencidos:

Que o imperialismo constitui atualmente e particularmente no Terceiro Mundo, um fator de desumanizaçáo que destrói os fundamentos da dignidade individual, atenta contra a livre manifestação da cultura, impede as formas autênticas de desenvolvimento humano e favorece situaçóes de subdesenvolvimento cada vez mais agudas e opressivas;

Que apesar das diferenças entre o cristianismo e o marxismo sobre a interpretação do homem e do mundo, é o marxismo que dá a análise científica mais precisa da realidade imperialista e os estímulos mais eficazes para ação revolucionária das massas;

Que o padre Camilo Torrès Restrepo deu, ao morrer pela causa revolucionária, o melhor exemplo do intelectual cristão comprometido com o seu povo.

NÓS NOS ENGAJAMOS na luta revolucionária anti-imperialista [sic], até as últimas consequências, para obter a completa libertação do homem e de todos os homens. (SIGNES DU TEMPS, 1958, p. 12) ${ }^{15}$.

15 Declaração assinada por Paul-Emmanuel Blanquart, Mgr Guzman, Juan Carlos Zaffaroni, Pedro de Excurdia, citado em Signes du temps, em abril de 1968. 
Em março de 1968, Paul Blanquart participa do simpósio "cristianismo e revolução" que reúne organizaçôes católicas progressistas. A moçáo final do colóquio reconhece o direito a todo cristáo de participar do processo revolucionário, inclusive através da luta armada ${ }^{16}$. Acusado de maniqueísmo, Paul Blanquart se justifica argumentando que a violência precede o revolucionário, pois é essa injustiça que engendra as estruturas sociais e políticas. Portanto, é "[...] a luta de classes objetiva que nos obriga a escolher nosso campo, e a não fazer isso dando apoio à injustiça presente" (BLANQUART, 1968, p. 14) ${ }^{17}$. Em maio de 1968, Paul Blanquart apoia por esse motivo a contestação estudantil e tenta, com diversas intervençôes, dotá-la de quadros de análise necessários para sua transformação em uma "revolução autêntica" (BLANQUART, 1968 b, p. 103-117) ${ }^{18}$. No dia 16 de maio, ele escreve um texto que será mimeografado no convento de Saint-Jacques de Marie-Dominique Chenu e depois difundido sob a forma de um folheto e amplamente publicado. Ele exorta os estudantes católicos a se juntarem à contestação:

Os estudantes e intelectuais cristãos estarão ausentes da elaboração coletiva desse projeto de civilização e da luta em que se formou? De minha parte, exorto-os a tomar seu lugar nesse projeto. O que está em jogo é da maior importância: uma vez que os cristãos são numerosos nessas categorias sociais hoje em uma situação revolucionária, uma oportunidade se apresenta para eles de que a Igreja seja parte ativa da revolução e, mais importante ainda, de imediato, que essa revolução esteja presente na Igreja. Não é nada menos que apagar o século XIX e o trágico divórcio que nele ocorreu entre a fé cristã e as forças revolucionárias da emancipação humana. (BLANQUART, 1968c, p. 7-10) 19 .

Em 21 de maio, Témoignage Chrétien publica um manifesto que convida os cristãos a trazer a revolução às Igrejas. Georges Montaron, Bernard Schreiner, Robert de Montvalon, Georges Casalis, Paul Ricoeur, Robert Davezies, Paul Blanquart, Marie-Dominique Chenu e muitos outros são signatários desse manifesto. Vários pequenos grupos respondem a esse apelo e amplificam seu efeito. O Comitê de Ação para a Revolução na Igreja (CARE) interrompe uma missa na igreja de Saint Séverin e tenta substituí-la por uma Assembleia Geral.

16 Christianisme et révolution, colóquio de 23 e 24 de março de 1968, suplemento de Lettre, n० 119, 1968.

17 Em Réponse à François Deltombe.

18 Conforme menciona no artigo Mai 68 en France, ou: du rationnel encore irrationnel face à l'irrationnel sous forme rationnelle.

19 Refere-se ao artigo Les étudiants et la révolution. 


\section{Uma redefinição política da vocação religiosa}

As organizaçôes cristấs e a instituição eclesial sairão debilitadas da agitação dos meses de maio e junho de 1968. A Igreja como instituição é desencantada porque a fé que ela codifica, as práticas que ela enquadra, os papéis que ela define são desqualificados como normas arbitrárias, burocráticas e alienantes. Muitos sacerdotes, após terem vivido com entusiasmo os meses de maio e junho, não conseguem se reconectar com a rotina sacerdotal anterior; a vida de padre lhes parecia inútil (CLEVENOT, 1989, p. 82-83). Na ordem dominicana esse desencantamento vai estimular um intenso desejo de refundação da vida religiosa ${ }^{20}$. Em julho de 1968, o provincial Nicolas Rettenbach cria uma comissão para refletir sobre a relação possível entre engajamento político e missão ${ }^{21}$. Paul Blanquart tem assento nela. Com outros religiosos do convento de Saint Jacques, Blanquart critica a ilusão da distinção entre o temporal e o espiritual e defende a necessidade de descompartimentar engajamentos políticos e religiosos: "Com efeito, nunca deixamos de estar no mundo e em suas solidariedades; é a partir daqui que buscamos realizar uma existência dominicana completa e autêntica, a serviço da Palavra" ${ }^{22}$. Segundo eles, o engajamento político é uma consequência inevitável dessa inversão da relação com o mundo: se o dominicano é solidário com o mundo, ele deve posicionar-se politicamente nele. Em julho de 1969, o capítulo provincial legitimará essa opção recomendando aos irmãos que se engajem em partidos políticos. Seguindo essa orientação, Paul Blanquart pregará dentro da sua ordem a politização da compreensão da vocação religiosa.

A cidade justifica hoje uma presença de religiosos? Sim, porque o mundo precisa de especialistas de ruptura. O princípio da vida religiosa é, em um mesmo movimento, provocar o mundo a abandonar a si mesmo e a passar de "Babilônia" para "Jerusalém". É em vista dessa ruptura, que é maior presença, que nos libertamos pela profissão dos três votos. A profissão é afirmação e compromisso em vista dessa presença específica no mundo.

20 A respeito de todo esse processo, ver: Raison Du Cleuziou, 2016.

21 A comissão era composta pelo freis: Ambroise-Marie Carré, Marie-Dominique Chenu, Vincent Cosmao, Jean-Pierre Jossua, Bernard Quelquejeu. Henri Burin des Roziers, Paul Blanquart, Yves Lebeaux, Jean Mansir. Seus arquivos são classificados com o do Capítulo Provincial de 1969, conforme APDF, III, G, 5I, 206.

22 Segundo APDF, III, G. 50, 205, resposta de Saint-Jacques assinada pelos freis: Remillieux, Georg, Lambert, Blond, Roqueplo, Houlmann, Mansir, Blanquart, Manigne, Alexandre, Milliard, Bussard, Duliscouët, Menuet, Gest, Raguénès, Revon, Lauchard. 
- A pobreza é a libertação de nossas energias e de nosso tempo para Deus e a contemplação. Ela é por si própria manifestação dessa ruptura, que é o próprio Deus. É também o poder de se afastar daquilo que causa a morte da cidade, o dinheiro (fuga necessária de todos os compromissos). É finalmente a indicação de outro uso do mundo, a partilha e a socialização.

- A Castidade. Seu princípio místico: “Eunucos... Entenda quem possa!”. Ela tem três justificativas essenciais, pois ela é: tomada de posição [em] face à reação dionisíaca; uma outra liberação de tempo para Deus; uma atualização da ruptura, tanto para si mesmo quanto para os outros.

- Obediência. Ela existe para a vida apostólica. O que está em jogo é demasiado importante e a tarefa é muito difícil para que não se tomem medidas necessárias contra a cegueira e a vontade própria. Frente à ruptura que nós temos que manifestar, somos demasiadamente responsáveis para podermos ser anárquicos e aberrantes. Isso implica coordenação, democracia, controle mútuo. No meio da "multidão solitária”, a vida comum é a libertação. O superior representa a vontade comum. Quanto à vontade comum, ela deve também permitir o exercício das liberdades "inspiradas". [...] (A palavra de Deus) deve existir neste mundo atual, isto é, ser capaz de uma eficácia social libertadora: trata-se de colocar a cidade em movimento. Manifestação da ruptura, ela se afirmará tanto melhor quanto mais abrupta for [...].

É necessário, ao mesmo tempo, proclamar o Evangelho de Jesus Cristo e transformar a situação. Trata-se do realismo do Evangelho. São Domingos não rompeu com as sobrecargas coletivas que impediam a Palavra de Deus de existir? Hoje, a fé exige que façamos parte de outra forma de civilização. Isso quer dizer que é necessário estar presentes para aqueles que fazem a cidade e contribuir para refazer o tecido da vida cotidiana. Mais concretamente ainda, isso significa que é necessário criar algo entre o indivíduo e o Estado (criação de comunidades de base, reivindicação de autogestão e de criação artística etc.) (BLANQUART, 1970, p. 3) ${ }^{23}$

A abordagem de Paul Blanquart mostra claramente uma forma de lealdade reivindicada pela vocação dominicana, mas reinterpretada em função das exigências de inserção "profética" no mundo. Segundo ele, o princípio instituinte da vida religiosa é a ruptura com o mundo. Esta é a condiçẫo do testemunho de um além do mundo: o Reino. No modo de vida religioso tradicional, esta vontade de ruptura se manifesta pelo convento, o enclausuramento, o hábito, o silêncio, os ofícios religiosos várias vezes por dia. Uma vez o convento contestado, quando ele já não é mais uma garantia de ruptura mas, ao contrário, parece fazer o jogo da ordem estabelecida, a modalidade de

23 APDF, IV, 4, J, 7I, em Notre identité dominicaine aujourd'hui (BLANQUART, 1970). 
ruptura com o mundo como condição do testemunho transforma-se em engajamento nas lutas sociais para construir uma sociedade mais justa, a adoção de uma postura militante e crítica a respeito daquilo que aliena os homens. De acordo com Paul Blanquart, é também esse dever de ruptura constitutiva da vocação dos irmãos que deve, de agora em diante, fazê-los romper com a própria instituição dominicana para salvar a sua finalidade: o testemunho de Deus na história humana: "Hoje, na contestação da Babilônia, constrói-se a nova Jerusalém” (BLANQUART, 1970, p. 2). Essa visão confere certa autoridade a Paul Blanquart no contexto de descobertas que sucede a maio de 1968. Em outubro de 1971, ele é nomeado Superior dos Estudantes pelo Conselho Provincial; mas, o Mestre da Ordem intervém para proibir essa nomeação devido às convicçóes marxistas da pessoa em questão (BLANQUART, 1970).

O dominicano Philippe Roqueplo, Conselheiro Eclesiástico da União dos Cientistas Católicos Franceses (USCF), desenvolve ideias convergentes com o pensamento de Paul Blanquart em seu livro L'Energie de la foi (1973). Segundo ele, a libertação dos homens é o horizonte concreto da salvação.

Quando Jesus declara: "O que você fez ao menor dos meus irmãos, é a mim que você fez", ele nos revela que o horizonte fraterno, o horizonte da cidade humana, o horizonte político é o verdadeiro horizonte da verdadeira liturgia: é aqui que nós realmente o servimos. É aqui que começa realmente nossa relação com Deus. E é por isso que, segundo o Evangelho, seremos finalmente julgados sobre o que teremos ou não teremos feito em relação aos homens. (ROQUEPLO, 1973, p. 136).

Ao tornar a história humana o lugar da ação religiosa, da verdadeira "liturgia”, Paul Blanquart e Philippe Roqueplo comprometem-se a repensar a vida religiosa. Segundo eles, os cristãos não podem se libertar das lutas humanas em nome de Deus. A separação do mundo é requalificada como via espiritual em traição aos Evangelhos. Philippe Roqueplo atribui legitimidade à contemplação, desde que ela não se torne um absoluto que substitua o dever de libertação dos homens. Porque o risco é que ela seja uma alienação que separa os homens de Deus: o próprio Deus presente em todos aqueles que sofrem e são dominados pela injustiça e pela opressão.

Os homens podem morrer, os trabalhadores podem experimentar ritmos insuportáveis, os norte-africanos e os portugueses estar estacionados em hotéis mobiliados; nossas cidades podem livrar-se de engarrafamentos e publicidade [...] os monges continuarão a procurar 
no ar o quadrado do céu azul que os domina e a contemplar assim, na harmonia do seu silêncio, o esplendor manifesto da glória de Deus. (ROQUEPLO, 1973, p. 145-146).

Na província dominicana da França, a partir de 1969, vários irmãos deixam os conventos para viver em apartamentos com um estilo de vida mais laico e, portanto, mais coerente com um trabalho profissional. Eles ambicionam encontrar as condiçóes para um renascimento da Igreja na nova sociedade que está nascendo. Alguns se inscrevem na linhagem dos padres-operários, outros são mais utópicos e inspirados pelo movimento das "comunidades de base" na América Latina. Seguindo esse movimento, Philippe Roqueplo, Paul Blanquart, Antoine Lion e François Leprieur deixam o convento de Saint-Jacques para se instalar em uma casa em Vanves em setembro de 1974. Um padre secular, Michel Clévenot, capeláo da Juventude Estudantil Cristá (JEC), popularizador da interpretação materialista dos Evangelhos ${ }^{24}$, irá morar com eles. Eles constituem um núcleo comunitário do movimento cristão-marxista.

\section{Uma politização do ministério sacerdotal ordinário}

Ao contrário dos sacerdotes do Echanges et Dialogues, que são a favor de uma desclericalização, Paul Blanquart não deseja renunciar à autoridade conferida pelo sacerdócio. Pois é um instrumento para politizar os leigos e, de maneira mais geral, a Igreja. Para esse fim, ele usa um repertório muito clássico de subjetivação. Por intermédio de intervenções escritas ou orais (conferências) ele mobiliza e dirige as consciências para levá-las a uma conversão ao cristianismo autêntico. De uma forma muito clerical, ele organiza a ortodoxia e a ortopraxia. Ocorre que o conteúdo dessas normas o coloca em posição de dissidência em relação ao magistério romano.

Paul Blanquart promove um novo relacionamento com as fontes da fé. Especialmente com a Bíblia. Como especialista do marxismo, participou com Michel Clévenot e Fernando Belo, um sacerdote português, de um grupo de reflexão criado em outubro de 1972 para reinterpretar os Evangelhos de uma perspectiva materialista (ROUSSEAU, 2009) ${ }^{25}$. Esses trabalhos culminarão

24 Intitulado Approches matérialistes de la Bible.

25 Para uma análise da época do fenômeno, consultar "Dossiê: C/X de Marx à Marc, l'Évangile mis à nu par la subversion de l'exégèse", publicado em Archives des Sciences Sociales des Religions, n. 40, 1975, 1975. 
com a publicação, em 1974, de um livro de exegese marxista que terá um grande impacto (BELO, 1974). A partir da uma análise do modo de produção da antiga Palestina e da ordem simbólica do antigo Israel, Belo reinterpreta os textos do evangelho de Marcos. As práticas de Jesus são requalificadas de maneira sociopolítica em função do contexto e das relações de força entre as classes. Eles não conduzem mais a uma compreensão religiosa instituindo a fé em uma salvação sobrenatural. A análise materialista "des-ideologiza" a fé colocando Jesus na tradiçáo popular e libertadora dos profetas ${ }^{26}$. A reformulação marxista da mensagem evangélica aboliu as distinções entre salvação e libertação, fé e política, igreja e socialismo, oração e ação. $\mathrm{O}$ cristianismo não aparece mais como um conjunto de valores aos quais se deve se conformar em vista de uma salvação, mas como uma prática de contestação do poder. Em última análise, a distinção entre os domínios espirituais e temporais é "apagada" e a libertação revolucionária requalificada como "atividade religiosa legítima" (SEVEGRAND, 1978, p. 261-264).

Segundo Paul Blanquart (1981, p. 107), essa exegese marxista desloca o entendimento comum da fé:

A Bíblia, na relação que o cristão tem com ela, funciona à maneira de uma memória atuante, de uma recuperação do passado para existir hoje em uma perspectiva de futuro. Quando 'celebra' o que ela está falando (a leitura é litúrgica), é para fazer-se existir na orientação que ela indica e que o próprio ato de leitura começa a constituir: a criação, a gestação de um novo mundo. Em outras palavras, a referência do crente à Bíblia, como um texto que lhe diz algo, não o coloca na condição de consumidor passivo, mas de um produtor de uma certa forma de existir hoje [...].

Perseguindo o gesto bíblico, a fé é assim “iniciação ou desgarramento, alargamento do horizonte, constituição nessa caminhada e esse horizonte expandido de um homem novo. Esse é o Deus vivo" (BLANQUART, 1981, p. 107). A fé é dinâmica de emancipação. Ela não existe fora dos atos que contribuem para a moldagem de uma nova sociedade. Onde ela é um corpus de crenças codificadas, não é mais do que uma ideologia, um discurso auto-referenciado separado do gesto profético. Para Paul Blanquart (1981, p. 109), o engajamento político marxista é a realização lógica da fé: "Não é nada

26 Conforme o dossiê “Les figures marxistes de Jésus”, Jésus?, n. 5, septembre 1974. 
surpreendente que o cristianismo, assim compreendido, exerça historicamente hoje, para numerosos militantes, um papel significativo no renascimento do projeto socialista revolucionário [...]".

A apologia da vida cristã que Paul Blanquart desenvolve no decorrer de suas intervençôes se constrói de maneira bastante clássica sobre os exemplos a seguir. Como os capelães costumam fazer, ele promove as normas da atitude católica legítima através de tipologias. Ele estabeleceu, por exemplo, uma das atitudes dos militantes católicos em maio de 1968. Ele vê na atitude do Témoignage Chrétien ou da Vie Nouvelle um entusiasmo religioso a respeito da contestação que é estéril por falta de compreensão da luta de classes. Ele também lamenta o cuidado excessivo da Ação Católica em relação ao movimento estudantil devido a uma "concepção estreita e setorial da luta socialista" (BLANQUART, 1981, p. 125). Pelo contrário, valoriza a atitude dos católicos revolucionários:

[Ele] começava a compreender que a Igreja e a sociedade eram inseparáveis, que as mesmas clivagens sociais, políticas e ideológicas atravessavam ambas; entrava assim no longo teste da crítica marxista do cristianismo e devia enfrentar o desafio de provar que a fé (mas qual?) é possível no interior de uma prática revolucionária. (BLANQUART, 1981, p. 126).

Paul Blanquart (1973, p. 109) desqualifica a abordagem explicitamente confessional. Qualquer rotulagem de uma ação movida pela fé em nome da "Igreja" ou mesmo da "fé" parece-lhe uma regressão ideológica. A missão é desqualificada pelo engajamento político que, bem melhor que ela, objetiva a fé vivida. Além disso, Paul Blanquart constata que, melhor que a "Igreja colonial”, os cristãos revolucionários da América Latina fazem com que os oprimidos sintam toda a verdade do cristianismo. Ele faz o panegírico dos mártires da autêntica fé: Juan García Ellorio, diretor da revista Cristiano y Revolução, assassinado; ou Domingo Lain, morto em combate:

Sua preocupação era política, não eclesial. Eles foram inteiramente queimados pelo sofrimento dos oprimidos, habitados por suas esperanças. Eu não acho que eles estavam tentando "reunir os cristãos", mesmo que fosse em posições progressistas. Eles eram revolucionários, totalmente. E é aí que a fé deles vivia, até eles morrerem. (BLANQUART, 1981. p. 14I) 27.

27 BLANQUART, P. Pour le 10e anniversaire de la mort de Camilo Torres. La Lettre, n. 212, auril 1976, reeditado em BLANQUART, P. En Batârdise, Itinéraire d'un chrétien marxiste. Paris: Karthala, 1981. p. 141. 


\section{Uma luta de classes na Igreja}

Os sacerdotes têm um papel de autoridade na Igreja. Suas palavras e também suas atitudes têm uma dimensão normativa, e é por essa razão que eles estão sujeitos a um controle estrito. Partidário de uma "nova igreja"28, Blanquart (1981, p. 122) acredita que o papel dos sacerdotes é essencial (PARAIT, 1973, p. 17-24). Por seus engajamentos na causa revolucionária, eles envolvem a Igreja na revolução e assim ajudam a transformá-la. Eles têm, portanto, um papel estratégico de maiêuticos de um cristianismo mais autêntico.

Para o Frei Blanquart, Camilo Torres é o modelo do sacerdote a seguir ${ }^{29}$. Envolvido na revolução como sacerdote, ele transformou ao mesmo tempo a Igreja e a revolução ao encarnar a possibilidade de sua aliança. Na sua esteira, muitos outros sacerdotes mantiveram durante suas vidas esse horizonte aberto. Assim como o padre português Maximino Barbosa de Sousa, morto pelos partidários de Salazar quando ia se candidatar, e que afirmava que "o sacerdócio deve sempre servir o povo, nunca se servir dele” (BLANQUART, 1976, p. 16). O mesmo com respeito ao dominicano Jean Raguenès, que na LIP (BLANQUART, 1978, p. 152) ${ }^{30}$ contribui para dotar o movimento operário de uma metafísica que lhe abre um horizonte utópico mobilizador ${ }^{31}$. Esses sacerdotes contribuem para a conversão da Igreja. Com toda a autoridade conferida a eles pelo sacerdócio, eles reconhecem a necessidade de conduzir a luta de classes na Igreja e se comprometem a "desenvolver a consciência e a combatividade popular” (BLANQUART, 1976, p. 16). Contra eles se dirige uma "burguesia eclesiástica" cujo estilo de vida, pregação e teologia legitimam os interesses da classe dominante (BLANQUART, 1976, p. 16). A recusa do engajamento político "os compromete com os defensores da ordem social" (BLANQUART, 1981, p. 152).

28 BLANQUART, P. Voici que je fais l'univers nouveau. Fraternité chrétienne avec le Vietnam, printemps-été, $n$. 8-9, 1973, reeditado em BLANQUART, P. En Batârdise, op. cit., p. 122.

29 Camilo Torres Restrepo (1929-1966), padre colombiano, sociólogo e militante de esquerda, juntou-se a um grupo guerrilheiro do Exército de Libertação Nacional (ELN) em novembro de 1965. Ele foi morto com armas em punho por tropas governamentais.

30 N.T.: Fundada por Emmanuel Lipmann, a fábrica LIP designa uma tradicional marca francesa de relógios originária de Besançon (Doubs). Ao longo da década de 1970, essa fábrica foi o palco da greve operária mais emblemática do pós-maio de 1968 na França, tendo suscitado, inclusive, abundante produção jornalística e cinematográfica.

31 BLANQUART, P. Des chrétiens d'après Mai. Rouge, 15 juin 1978, reeditado em BLANQUART, P. En Batârdise, op. cit., p. 152. 
Paul Blanquart assumirá pessoalmente essa forma de sacerdócio de combate por sua escrita. Com Philippe Roqueplo, é membro da equipe editorial do semanário Politique-Hebdo desde sua criação, em 1970. O semanário fundado pelo dissidente comunista Paul Noirot reúne todas as tendências da esquerda marxista ou de inspiração marxista que criticam o PCF. Philippe Roqueplo é cronista de notícias científicas e Paul Blanquart mais generalista. O provincial Nicolas Rettenbach autorizou e apoiou seu engajamento. Eles não escrevem (apenas) sob pseudônimos, mas não acrescentam qualquer referência à sua afiliação dominicana após sua assinatura. Seu status religioso é de todo modo conhecido, mas eles jogam com ele para explicitar a autenticidade de seu posicionamento. Eles se qualificam de cristãos revolucionários e insistem em seu duplo enraizamento, autenticamente cristão e autenticamente marxista.

Suas tomadas de posição na Politique-Hebdo se inscrevem em um contexto de recomposição da esquerda católica. Após maio de 1968, as principais organizaçôes católicas "em busca" estão tentando se organizar. Inicialmente focado em torno das comunidades de base e, sobretudo, da comunidade de Boquen, certo número de movimentos que têm em comum uma contestação da instituição eclesial e um posicionamento político à esquerda tentam se federar. A partir de 1970, eles se reúnem todos os anos: Bourges (1970), Rouen (1971), Rennes (1972), Lyon (1973) e Dijon (1974) ${ }^{32}$.

A busca pela unidade tropeçará na questão política. À medida que a esquerda francesa se recompóe na década de 1970, a esquerda católica deve se posicionar. Sem elaborar um inventário exaustivo, é notável, por exemplo, que La Vie Nouvelle, Témoignage Chrétien e uma parte das comunidades de base são favoráveis à União da esquerda. Ao contrário, o Círculo João XXIII, Lettre, e uma minoria ativa do Movimento Rural da Juventude Cristã (MRJC), são a favor de um apoio à extrema esquerda.

Philippe Roqueplo e Paul Blanquart fazem parte dessa última tendência. Eles trabalham para que os católicos se engajem em uma atitude revolucionária marxista. Eles recorrem às suas diversas qualificaçôes de teólogo ou jornalista para exercer influência nessa direção. Sob o pseudônimo de André Parait, Paul Blanquart denuncia na Politique-Hebdo os riscos de caducidade

32 Sobre toda essa história, ver: Soulage, 2015. 
da revolução que uma aliança entre a Igreja e o Partido Comunista poderia implicar. Ele qualifica de reformista a posição do Témoignage Chrétien porque o hebdomadário se satisfaria com uma reorientação da Igreja sem alteração das estruturas teológicas e institucionais. Para Paul Blanquart, a estratégia da "mão estendida" do PCF favorece diretamente essa linha. Por repousar sobre um status quo fundado sobre uma estrita delimitação entre o reino temporal e o domínio espiritual, ela compartilha o poder entre a burocracia eclesial e a do PCF, obstruindo a luta de classes. Assim, em fevereiro de 1972, por ocasiáo da chegada dos representantes católicos na Semana do pensamento marxista, Paul Blanquart critica o PCF por procurar interlocutores oficiais em vez dos minoritários e críticos na Igreja (PARAIT, 1972a). Segundo ele, é a luta de classes e não a distinção entre temporal e espiritual que deve orientar a estratégia da PCF a respeito da Igreja: ele deve apoiar na Igreja, como em qualquer outro lugar, as minorias revolucionárias que estão engajadas nessa luta.

Paul Blanquart mobiliza sua competência sacerdotal de uma maneira subversiva: usa sua autoridade contra a instituição de que é mandatário. Cristão-marxista assumido, ele luta em um duplo front: como cristão, ele trabalha para contestar as interpretaçôes fideístas de Marx no interior dos movimentos marxistas; como marxista, ele trabalha para libertar a Igreja da ideologia burguesa para engajar os católicos na luta de classes (PARAIT, 1972b). Ele se situa ao mesmo no domínio religioso e no domínio político. Recusando-se a distinguir os dois, e suas críticas se dirigem tanto às organizaçôes católicas quanto às organizaçóes políticas de esquerda. Blanquart coloca ombro a ombro o "clero" do PCF e o clero católico. A Igreja e o PCF são, para ele, duas instituiçóes análogas que capturaram a mensagem evangélica e o marxismo em vista de suas próprias estratégias de poder institucional. A Igreja trai Jesus, como o PCF trai Marx. A libertação desses poderes "constantinianos" deve vir da luta unitária entre a extrema esquerda e os católicos. Paul Blanquart usa o Politique-Hebdo como instrumento dessa integração recíproca entre a extrema esquerda e a Igreja.

Politique-Hebdo realiza, em uma escala nunca antes alcançada na França até o presente, a integração em um combate comum dos militantes cristãos e militantes marxistas, muito além do "diálogo" desses últimos anos em que os aparelhos eclesiásticos e os comunistas oficiais gostariam de se confinar. (BLANQUART, 1971, p. 5). 
O pertencimento à Igreja como religioso é crucial para Philippe Roqueplo e Paul Blanquart porque os autoriza como clérigos a transformar a Igreja desde o interior. O seu status clerical é igualmente útil na política, pois, em virtude de se engajarem como dominicanos, eles abrem a esquerda para uma aliança revolucionária com os cristãos. A sua homologia de posição nos espaços políticos e religiosos é a condição de suas práticas subversivas, posto que quais críticas legítimas eles poderiam fazer da teologia sem ser teólogos? Nenhuma. A exigência é idêntica para o marxismo.

Em que consiste, ao contrário, a luta dos cristãos revolucionários? A fé pela qual eles lutam - e que eles acreditam estar na linha direta de Abraão deixando Ur da Caldéia, do povo hebreu e de Moisés saindo da escravidão, onde os faraós do Egito os submetiam etc. - consiste em se afastar de todos os determinismos, todas as fatalidades, e em um alargamento infinito do horizonte humano. É, portanto, ela que faz com que eles lutem, hoje, pelo socialismo. [...] Certamente alguns deles são sacerdotes. Por quê? Porque eles não querem deixar o campo de fé aos seus adversários na Igreja (como o revolucionário na empresa ou sociedade) para arrancar a tradição bíblica daqueles que a desviaram a serviço dos poderosos e dos exploradores. (PARAIT, 1972c, p. II).

Por que, sendo sacerdotes e dominicanos, nos engajamos nessa aventura? Saímos da Igreja por essa razão? Ou estávamos, ao contrário, mais ou menos autorizados a exercer não sei qual influência clerical no seio da luta revolucionária. Bem, nem um nem o outro. Nós permanecemos cristãos, sacerdotes e dominicanos integralmente. [...]. É um fato: qualquer que seja o pensamento do clero de um lado ou de outro, há hoje homens - e muitos - que se afirmam ao mesmo tempo marxistas e cristãos". (ROQUEPLO, 1971, p. 5).

Como religiosos, sacerdotes e teólogos, Paul Blanquart e Philippe Roqueplo frequentemente tomam a palavra em organizaçóes católicas, como o JEC ou o MRJC, para promover a reconciliação entre fé e marxismo. Eles contribuíram amplamente para qualificar o marxismo e os compromissos políticos na extrema esquerda como práticas religiosas legítimas.

De 1973 a 1974, as divisóes entre cristãos ativistas se aprofundaram. Paul Blanquart se questiona, entấo, sobre a conveniência de criar um movimento autônomo reunindo apenas os cristãos revolucionários:

Para que essa força histórica se desenvolva, em vez de se afogar entre os "cristãos em busca" e usar suas energias, não seria melhor que os cristãos marxistas se organizassem entre eles, com sua própria imprensa, lançando seus próprios centros de estudos, suas próprias assembleias? O debate está aberto. (BLANQUART, 1974, p. 13). 
Em junho de 1974, durante a segunda "Assembleia de Cristãos em busca" em Dijon, um "fórum de iniciativa revolucionária” separa o Grupo de Ligação e os Cristãos Críticos da Informação (GLICC). A iniciativa vem de La Lettre, do Vaugirard 46, do Círculo Jean XXIII e de diversos outros militantes de extrema esquerda. Ela dá origem a um movimento "Cristão- marxista". Em 12 e 13 de outubro de 1974, o novo grupo se reunirá em Chevilly-Larue para sua primeira reunião. Decidiu-se formar um movimento cristão-marxista autônomo. Paul Blanquart, Philippe Roqueplo e Antoine Lion, participam dele. Em 1975, os cristãos marxistas assumiram a revista Cité nouvelle, anteriormente ligada ao Cristianismo Social, para fazer dela seu boletim oficial ${ }^{33}$. A linha continua a mesma: enfrentar de frente a crítica da Igreja e do PCF em nome da luta de classes. O movimento Cristãos-marxistas prolonga e institucionaliza o jogo subversivo dos dominicanos. Em 1976, enquanto Georges Marchais fazia um "apelo aos cristãos da França", Paul Blanquart denuncia mais uma vez o "Pacto Constantiniano", que coloca o PCF na "via de integração aos quadros ideológicos e institucionais da sociedade burguesa" (BLANQUART, 1976b, p. 8). Contudo, Cité nouvelle visa mais aos católicos do que aos comunistas. Os cristáos marxistas pensam em si mesmos como o instrumento da conversão da Igreja (ROQUEPLO, 1978).

\section{Um engajamento clerical criticado}

Naturalmente, o jogo subversivo de alguns dominicanos marxistas-cristãos não é uma unanimidade. Estes são criticados à esquerda por um religioso dominicano também marxista, mas de obediência trotskista. O Frei Dominique, depois de se engajar com a CGT nas lutas sindicais que atravessam seu empreendimento, estabelece relaçóes de estima e interesse com os militantes da Organização Comunista Internacionalista (OCI) e decide juntar-se a eles. Os líderes da OIC exigem sua ruptura com a Ordem Dominicana como condição para sua adesão. Ele aceita e sai da Ordem. Sua decisão provoca a reprovação dos dominicanos que compartilham com ele, no entanto, uma posição "de esquerda". De fato, Frei Dominique se vê criticado por esses religiosos por abandonar a luta revolucionária dentro da Igreja. Frei Dominique, por sua

33 A maioria dos artigos não estando assinados, torna-se dificil apreciar exatamente a participação dos dominicanos, mesmo ela tendo sido importante: entrevista com Antoine Lion, em 20 de abril de 2007. 
vez, denuncia a estratégia daqueles religiosos, por ser parte um reformismo conservador.

Podemos nos unir às fileiras da classe trabalhadora na batalha pela ditadura do proletariado e pertencer a uma instituição reconhecida pela classe trabalhadora como suporte da ordem estabelecida? Fui objetado porque os irmãos envolvidos na luta política, ou mais geralmente, na luta pela libertação do "homem”, não sentiram a necessidade de deixar a Ordem, que para alguns o período que atravessava a Igreja era um período transitório, e que nós devíamos trabalhar de dentro para levar a Igreja para o campo da classe operária. Ou esses irmãos vivem na esperança da Segunda Vinda, pelo que não poderia reprová-los, ou então, e esta é a minha conclusão, eles contribuem, de fato, conscientemente ou inconscientemente à manutenção da ordem burguesa $[\ldots]^{34}$.

Os cristãos-marxistas, evidentemente, são igualmente criticados pela direita. Na Ordem Dominicana, muitos religiosos denunciam as posiçôes de Philippe Roqueplo e Paul Blanquart e a proteção que desfrutam ao nível provincial. Serge Bonnet (1973) se dirige a eles em vários aforismos de seu panfleto $A$ hue et à dia. Ele lhes reprova seu clericalismo autoritário e seu dogmatismo. De qualquer maneira, Paul Blanquart não faz nada para se esquivar das críticas. Ele se define publicamente como um crente ateu:

Eu não acredito em um ser metafísico fora da história nem em uma sobrevida pessoal após a morte. No entanto, Deus tem um significado para mim: é a presença de uma ausência. Eu vivo em algo que não existe, mas que me motiva e me torna diferente. Eu sou um ateu e eu sou um crente. (WOODROW, 1978, p. 14).

Um frade dominicano irá escrever para ele pedindo que deixe a Ordem; mas, Paul Blanquart responde que sua fé é mais autenticamente cristã que a ideologia da fé disseminada pelo magistério romano. Esse tipo de posição se torna mais perigosa após a eleição de João Paulo II em 1978. Com o horizonte de uma possível reforma tornando-se cada vez mais incerto, muitos católicos contestadores fazem a escolha de tomar sua distância com relação à Igreja. Philippe Roqueplo deixa a vida religiosa em 1977 devido a seu conflito com as autoridades eclesiásticas sobre o aborto. Ele é a favor da legalização. Em 1978, afetado pela crise do marxismo, é o próprio movimento Cristão-Marxista que se autodissolve (TRANVOUEZ, 2015). Philippe Roqueplo, em um artigo

34 APDF, III, M, 7, Carta de Dominique Barbier, junho de 1973. 
amargo, tenta identificar as causas da deriva grupal da corrente. Ele lamenta retrospectivamente a captura clerical do movimento: "Cristãos- Marxistas" era um assunto de clérigos e [...] estou tentado a ver aí o motivo que reduziu consideravelmente seu campo de preocupações e, por essa mesma razão, seu impacto" (ROQUEPLO, 1978, p. 14). Após 1978, os dominicanos engajados como Cristão-Marxistas continuarão sua militância de uma maneira mais secular, sem colocar seu status de sacerdócio à frente.

\section{Conclusão}

Durante os anos 1960 e 1970, as trajetórias e as modalidades de politização dos sacerdotes não são todas idênticas. Aquelas que estudamos são particularmente interessantes porque o próprio status de sacerdote é reinterpretado como um instrumento político. Para Paul Blanquart estava claro que a militância de um padre não tem o mesmo alcance que a ação de um leigo. Somente o sacerdote, por sua autoridade simbólica, envolve a Igreja ao se engajar e, consequentemente, modifica a sua percepção social.

Dessa forma, a politização dos sacerdotes possui uma dimensão iconoclasta. Ao aparecer na tribuna, marchando entre os manifestantes, assinando um manifesto, reivindicando o marxismo, ela rompe o monopólio das autoridades eclesiais sobre a ortodoxia e a ortopraxia. Eles dão à Igreja uma nova imagem e tornam possível outra. A Igreja Católica da França e, além dela, as Igrejas europeias, atravessam uma crise simbólica durante a década de 1960. O "regime de sacramentalidade" instituído parece ser cada vez menos, para os militantes cristãos, uma forma relevante de objetivação da mensagem evangélica (CERTEAU, 2003, p. 302). A politização de Paul Blanquart ou Philippe Roqueplo pode ser interpretada como uma estratégia de institucionalização de uma nova sacramentalidade, ou seja, de um novo regime de verdade católica. Eles são empreendedores de revolução simbólica e, como tal, suas tomadas de posição poderiam ser comparadas com outras formas de contestaçóes religiosas (CHRISTIN, 1991). As lutas sociais, as mobilizaçôes, os "manifestos", as petiçôes, não poderiam se tornar religiosamente qualificadas como via de salvação e de anúncio do Reino sem uma institucionalização de seu caráter religioso. Elas são contaminadas, isto é, requalificadas religiosamente, pela 
presença dos sacerdotes que se engajam nesses movimentos ${ }^{35}$. Os sacerdotes são os especialistas autorizados na manipulação da verdade por meio de formas. Eles podem envolver Deus com suas açóes e suas palavras. Eles dispóem, portanto, de uma competência à contestação e à subversão das formas eclesiais instituídas que não são possuídas por aqueles que não gozam de um papel de autoridade na instituição. O carisma de função é a condição do peso subversivo das práticas. As vanguardas eclesiais tiveram "estratégias de poder" e procuraram "papéis de autoridade" para esse fim (BONNET, 1973, p. 252). Os historiadores do catolicismo contemporâneo até agora não prestaram verdadeiramente atenção a este aspecto vital da "crise católica".

A importância do carisma de função explica que a reivindicação de fidelidade e da obediência seja tão importante e, portanto, tão controversa durante os anos estudados. Os dominicanos se dilaceram para definir qual interpretação da vocação dominicana é legítima ou para romper o limite a partir do qual a pesquisa teológica torna-se desviante. Esta concorrência para impor a ortodoxia e a ortopraxia apenas é possível em um contexto mais global de incerteza institucional. Ou seja, quando as maiores autoridades eclesiais parecem duvidar dos fundamentos da autoridade que exercem; como pode ser observado com as tergiversaçóes dos bispos franceses na publicação da Humanae Vitae. A politização como forma de ação religiosa iconoclasta pode, então, ter um poderoso significado simbólico e criar uma relação de força na Igreja.

Após a eleição de João Paulo II e a reafirmação da autoridade hierárquica na Igreja, o equilíbrio de poder se altera e a iconoclastia das vanguardas se torna desvalorizada como prática marginal sem alcance prescritivo possível. Os sacerdotes contestadores náo se beneficiam mais da ambiguidade do contexto eclesial ou social e sua margem de jogo com seu carisma de função é reduzido. Eles se automarginalizam na Igreja ou retornam ao estado secular. Mas a ruptura com o sacerdócio acaba por fazê-los perder todo o crédito na luta em que eles se envolveram para fazer surgir uma nova Igreja. Também é sintomático que uma vez retornadas ao estado secular, as carreiras contestatárias dos padres se interrompem, tanto na Échanges et Dialogue quanto na Província Dominicana da França. Por mais paradoxal que isso possa parecer, a inovação

35 Sobre essa noção de contaminação religiosa, consultar Les formes élémentaires de la vie religieuse (DURKHEIM, 1979, p. 454-459). 
simbólica é possível apenas no âmbito da instituição que ela desafia. $\mathrm{O}$ carisma de função é sua condição e seu limite.

\section{Referências}

BARRE, N. Jésuites et ouvriers. La mission ouvrière jésuite de 1944 à la fin des années 1990. Paris: Karthala, 2014.

BELO, F. Lecture matérialiste de l'évangile de Marc. Paris: Cerf, 1974.

BIZOT, J.-F. Chrétiens de gauche: les fidèles cassent trop. Actuel, n. 51, p. 27-33, février 1975 .

BLANQUART, P. Réponse à François Deltombe. Signes du temps, n. 5, p. 14, mai 1968a.

. Mai 68 en France, ou: du rationnel encore irrationnel face à l'irrationnel sous forme rationnelle. Politique et prophétisme, mai 1968. Centre catholique des Intellectuels Français, recherches et Débats. Paris: Desclée de Brouwer, 1968b.

. Les étudiants et la révolution. Signes du temps, n. 6, p. 7-10, juin 1968c.

- Notre identité dominicaine aujourd'hui. Saint-Jacques informations, $\mathrm{n}^{\circ}$ spécial retraite conventuelle, p. 3, $1^{\text {er }}$ octobre 1970.

. Chrétiens dans la révolution. Politique-Hebdo, n. 28, p. 5, jeudi 29 avril 1971.

. Foi chrétienne et gauchisme. La Lettre, n. 173, janvier 1973.

. Chrétiens en recherche et réformisme. Cité nouvelle, n. 562, mai 1974.

. On l'appelait Max. Cité nouvelle, n. 580, mai 1976a.

. Un pacte constantinien. Témoignage Chrétien, jeudi, p. 8, 17 juin 1976 b.

et al. Qu'apportons-nous de neuf à l'Église et aux autres ?. Autrement, n. 8, 1977.

. Cité nouvelle, n. 594, p. 13-15, sept. 1978.

. En batârdise. Itinéraire d'un chrétien marxiste. Paris: Karthala, 1981.

BLOND, P. Prêtre dans un parti. Parole et Mission, n. 56, p. 256, 20 mai 1971.

BONNET, S. A hue et à dia, les avatars du cléricalisme sous la V ${ }^{\mathfrak{e}}$ République. Paris: Cerf, 1973.

BOURDIEU, P.; SAINT-MARTIN, M. de. La sainte famille, l'épiscopat français dans le champ du pouvoir. Actes de la Recherche en Sciences Sociales, n. 44/45, p. 2-53, nov. 1982. 
BOUSQUET, M. Les aumôniers de la subversion. Quand le clergé terrifie le patronat. Le Nouvel Observateur, p. 27, 19 avril 1971.

BRION, M. La religion vécue des français. Paris: Cerf, 1972.

CERTEAU, M. De. La faiblesse de croire. Paris: Seuil, 2003.

CHRISTIN, O. Une révolution symbolique, l'iconoclasme huguenot et la reconstruction catholique. Paris: Minuit, 1991.

CLEVENOT, M. Approches matérialistes de la Bible. Paris: Cerf, 1976.

Haut-le-pied, itinéraire d'un homme de foi. Paris: La Découverte, 1989.

DAVODEAU, É. Les mauvaises gens: une histoire de militants. Paris: Delcourt, 2005.

DELOYE, Y. Les voix de Dieu, Pour une autre histoire du suffrage électoral: le clergé catholique français et le vote (XIX ${ }^{\mathrm{e}}-\mathrm{XX}^{\mathrm{e}}$ siècle). Paris: Fayard, 2006.

DURKHEIM, É. Les formes élémentaires de la vie religieuse. Paris: PUF, 1979.

FOUILLOUX, É. 40 ans de "main tendue" et ceux qui l'ont prise. Autrement, n. 8, p. 102, 1977.

GRIGNON, C. Sur les relations entre les transformations du champ religieux et les transformations de l'espace politique. Actes de la Recherche en Sciences Sociales, n. 16, p. 3-34, 1977.

PAGIS, J. La politisation d'engagements religieux. Retour sur une matrice de l'engagement en mai 68. Revue Française de Science politique, v. 60, p. 61-89, 1/2010.

PARAIT, A. Le PC au secours de toutes les églises. Politique-Hebdo, n. 15, p. 12-13, 10 février 1972a.

$1972 b$.

. Les révolutionnaires et l'église. Politique-Hebdo, jeudi, n. 23, p. 19-20, 6 avril

\section{2 .}

. Cléricalismes rouge et noir. Politique-hebdo, jeudi, n. 47, p. 11, 5 oct. 1972c

. Du sanctuaire à l'affrontement. Politique-Hebdo, n. 61, p. 17-24, janvier 1973.

PELLETIER, D. ; SCHLEGEL, J.-L. (Dir.). À la gauche du Christ, une histoire des chrétiens de gauche. Paris: Seuil, 2015.

PEYREFITTE, C. Le clergé français est-il en crise ?. Commentaire, n 2, p.été 1978. 
RAISON DU CLEUZIOU, Y. Les frères étudiants dominicains dans la guerre d'Algérie: une étape de la remise en cause des formes de la vie religieuse. In : LALOUETTE, J.; BLENNERMICHEL, S. (Dir.). Servir Dieu en temps de guerre $\left(\mathbf{X I X}^{\mathbf{e}}-\mathbf{X X}^{\mathbf{e}}\right)$. Paris: Armand Colin, 2013. p. 295-310.

Devenir homme parmi les hommes. Révolution ascétique et redéfinition de la virilité sacerdotale au milieu du XX ${ }^{\text {e }}$ siècle. In : BREJON DE LAVERGNEE, M. ; DELLA SUDDA, M. (Ed.). Genre et christianisme. Plaidoyers pour une histoire croisée. Paris: Beauchesne, 2015. p. 257-285.

De la contemplation à la contestation. La politisation des dominicains de la Province de France (Années 1940-1970). Paris: Belin, 2016.

REMOND, R. Lévolution du comportement des prêtres en matière politique. In:

Politique et foi. Strasbourg: CERDIC, 1972. p. 80-100.

RETTENBACH, N. Note du Prieur Provincial. Ut sint unum, n. 355, $1^{\text {er }}$ juin 1972.

ROQUEPLO, P. Un prêtre s'explique. Politique-Hebdo, jeudi, n. 28, p. 5, 29 avril. 1971.

L'énergie de la foi, science, foi, politique. Paris: Cerf, 1973.

. Ce que je pense des chrétiens marxistes. Cité Nouvelle, n. 593, p. 14, sept. 1978.

ROUSSEAU, A. Les classes moyennes et l'aggiornamento de l'Église. Actes de la Recherche en Sciences Sociales, n. 44/45, p. 55-68, nov. 1982.

ROUSSEAU, S. François Biot, la foi et la politique. Une conjoncture théologique au tournant des années 1960. In: BECKER, A. et al. Ecrire l'histoire du christianisme contemporain. Autour de l'œuvre d'Etienne Fouilloux. Paris: Karthala, 2013. p. 347-360.

Lectures militantes de la Bible dans les années 1970. Siècles, v. 29, 2009. Disponível em: <http://siecles.revues.org/535>. Acesso em: 22 mar. 2017.

SOULAGE, V. L'engagement politique des chrétiens de gauche, entre Partis Socialiste, deuxième gauche et gauchisme. In: PELLETIER, D.; SCHLEGEL, J.-L. (Dir.). À la gauche du Christ, une histoire des chrétiens de gauche. Paris: Seuil, 2015. p. 425-456.

SEVEGRAND, M. Parmi les chrétiens de gauche... des chrétiens-marxistes. Marxisme vivant, pratiques et réflexions de militants. Lettre, p. 2061-264, 1978.

SIGNES DU TEMPS, n. 4, p. 12, avril 1968.

SIMEANT, J. Immigration et action collective. L'exemple des mobilisations d'étrangers en situation irrégulière. Sociétés Contemporaines, n. 20, p. 39-62, 1994. 
SONDAGES. Les prêtres. Elections des 4 et 11 mars 1973. N. 1, p. 26-30, 1973.

SUAUD, C. La vocation: conversion et reconversion des prêtres ruraux. Paris: Minuit, 1978. . Conditions et limites de la reconversion des prêtres en milieu rural. In: Prêtres, pasteurs et rabbins dans la société contemporaine. In: COLLOQUE DU CENTRE DE SOCIOLOGIE DU PROTESTANTISME. Paris: Cerf, 1982. p. 237.

TRANVOUEZ, Y. 1975-1981. Du matérialisme au retour du spirituel. In: PELLETIER, D.; SCHLEGEL, J.-L. (Dir.). À la gauche du Christ, une histoire des chrétiens de gauche. Paris: Seuil, 2015. p. 425-456.

WOODROW, A. La foi décapée. Le Monde, 23 février 1978.

\section{Fontes Documentais}

ARQUIVOS da Província Dominicana da França (APDF). III, G: Chapitres provinciaux. ARQUIVOS da Província Dominicana da França (APDF). III, L: Les institutions de formation.

ARQUIVOS da Província Dominicana da França (APDF). III, M: Dossiers personnels des frères au secrétariat provincial.

ARQUIVOS da Província Dominicana da França (APDF). III, O: Activités minitères. 84. Documents sur l'objection de conscience.

ARQUIVOS da Província Dominicana da França (APDF). IV, 4: Saint-Jacques.

ARQUIVOS da Província Dominicana da França (APDF). IV, 201. Studentat. O, 1. Vacances, 1959-1971. 


\section{The sacerdotal politicization as religious iconoclasm: the case of the Dominicans engaged in the Christian-Marxist movement}

\section{Abstract}

After May 68, some priests involved in politics put forward their priestly authority. They hope thus to contribute to engaging the Church in the class struggle and also restoring the prophetic radicalism of Christian faith. Their political mobilization has a religious reforming purpose. It is this form of politicization of sacerdotal competence that is here studied more particularly through the example of the Dominicans of the Province of France members of the Christian-Marxist movement (1974-1978).

Keywords: Catholicism. Dominicans. Marxism. Politicization.

Recebido em: 01.07.2017.

Aprovado em: 23.08.2017. 